\title{
Disinfection performance of a drinking water bottle system with a UVC LED cap against waterborne pathogens and heterotrophic contaminants
}

Richard M. Mariita ${ }^{1 *}$, Sébastien A. Blumenstein ${ }^{1}$, Christian M. Beckert ${ }^{2}$, Thomas Gombas $^{2}$, Rajul V. Randive ${ }^{1}$

${ }^{1}$ Crystal IS Inc., an Asahi Kasei company, 70 Cohoes Avenue, Green Island, New York, 12183, USA

${ }^{2}$ Purgaty gmbh Albertgasse 39/15 1080, Vienna, Austria

*Corresponding author: richard.mariita@cisuvc.com

\section{Abstract}

Background: The purgaty One systems (cap+bottle) are portable stainless-steel water bottles with ultraviolet subtype C (UVC) disinfection capability. This study examines the bottle design, verifies disinfection performance against Escherichia coli, Pseudomonas aeruginosa, Vibrio cholerae and heterotrophic contaminants and addresses the public health relevance of heterotrophic bacteria. Methods: Bottles were inoculated with bacterial strains and disinfection efficacy examined using colony forming unit (CFU) assay. The heterotrophic plate count (HPC) method was used to determine the disinfection performance against environmental contaminants at day 0 and after 3 days of water stagnation. All UVC irradiation experiments were performed under stagnant conditions to confirm that the preset application cycle of 55 seconds offers the desired disinfection performance under worst case condition. To determine effectiveness of purgaty One systems (cap+bottle) in disinfection, inactivation efficacy or log reduction value (LRV) was determined using bacteria concentration between UVC ON condition and controls (UVC OFF). The study utilized the 16S rRNA gene for isolate characterization by identifying HPC bacteria to confirm if they belong to groups that are of public health concern. Results: Purgaty One systems fitted with Klaran UVC LEDs achieved $99.99 \%$ inactivation (LRV4) efficacy against $E$. coli and $99.9 \%$ inactivation (LRV3) against $P$. aeruginosa, V. cholerae and heterotrophic contaminants. Based on the 16S rRNA gene analyses, the study determined that the identified HPC isolates enriched by UVC irradiation are of rare public health concern. Conclusion: The bottles satisfactorily inactivated the target pathogenic bacteria and HPC contaminants even after 3 days of water stagnation.

Keywords: Cholera, Disinfection, Escherichia coli, Pseudomonas aeruginosa, Public Health, UVC LED, Vibrio cholerae, Water treatment 


\section{Abbreviations:}

ATCC: $\quad$ The American Type Culture Collection

CFU: $\quad$ Colony Forming Units

LRV: $\quad$ Log Reduction Value

PBS: $\quad$ Phosphate Buffered Solution

PCR: $\quad$ Polymerase Chain Reaction

POE: $\quad$ Point of Entry

POU: $\quad$ Point of Use

rRNA: $\quad$ Ribosomal RNA

TDS: $\quad$ Total Dissolved Solids

UVT : $\quad$ Ultraviolet Transmittance

UVC : $\quad$ Ultraviolet Subtype C

\section{Introduction}

The low quality of potable water is a major issue in travel medicine, especially when visiting places with poor hygienic conditions due to waterborne diseases which pose substantial health risk [1]. Waterborne pathogens, predominantly of fecal origin, can be transmitted via contaminated drinking water [2]. Even in developed countries, they represent a risk to recreational travelers who have to rely on surface water [1]. For instance, in the United States, it is estimated that each year 560,000 people suffer from severe waterborne diseases due to the consumption of contaminated drinking water, with 7.1 million suffering from mild to moderate infections, resulting in estimated 12,000 deaths a year [3]. Hikers and campers are also exposed to waterborne disease risks if they consume untreated water from rivers and lakes [4]. Diarrheal infections are a major inconvenience in the wilderness during hiking or camping and can easily spread via contaminated water supplies and from person-to-person.

One way to prevent waterborne diseases for healthy travelling in regions with unsafe or underdeveloped water sources, is by ensuring adequate supply of potable water.

Alternatively, outdoor enthusiasts can use portable and germicidal devices that ensure inactivation of microbial contaminants. Ultraviolet irradiation in the UVC range (200$280 \mathrm{~nm}$ ) has demonstrated effective inactivation of microbial contaminants in water [5]. Specifically, as part of the effort to accelerate the sustainable development goals (SDG) such as clean water and sanitation goal (SDG \#6) [6], regulating microbial load is required to control waterborne diseases caused by microorganisms such as Pseudomonas aeruginosa, Escherichia coli and Vibrio spp. [7].

Cholera, caused by Vibrio cholerae remains a serious risk in emerging economies where sanitation is poor, health care limited, and drinking water unsafe [8]. Additionally, due to global warming, there is association between the spread of pathogenic vibrios and emergence of human diseases towards the temperate world [9]. Existing water infrastructure including electronic faucets can act as reservoirs and sources of outbreaks once contaminated. Hospital water, for instance, can disseminate 
opportunistic pathogens such as Pseudomonas aeruginosa and fecal coliforms, where Escherichia coli is a key species [10].

Furthermore, heterotrophic bacteria are a concern in drinking water systems if the counts are consistently $>500 \mathrm{CFU} / \mathrm{mL}$. They can be an indication of general decrease in water quality and potential biofilm formation in municipal water [11]. Therefore, to eradicate elevated levels of HPC and other pathogens, portable bottle devices with disinfection features can act as a form of disinfectant.

With more than 1 billion people globally having no access to potable water, and 2.4 billion people still living in areas without adequate sanitation systems [12], there is need for portable, durable, appealing, personal and highly germicidal devices to help curb enteric pathogens. Use of UVC radiation is one of the disinfection methods recognized by WHO [12]. Unlike most methods, UV disinfects by striking the target microorganism with sufficient dose of energy, while neither altering the water, nor providing any residue [12]. UV is subdivided into three distinct bands: UVA with a wavelength of $315-400 \mathrm{~nm}$, UVB with 280-315 nm, and UVC with 100-280 nm [13]. The UVC region has been found to be effective against waterborne pathogens [14]. Specifically, the wavelength range between $250-270 \mathrm{~nm}$, is strongly absorbed by the nucleic acids of microbial cells [15]. Theoretically, the disinfection performance of a UVC device is a function of the intensity of UVC light (irradiance) and time of exposure resulting in a UVC dose. Greater disinfection efficacy is expected at higher UVC dose [16].

The purpose of this study was to investigate the disinfection performance of the recent commercial development of the portable purgaty ${ }^{\circledR}$ One system (cap+bottle) by analyzing test bottles against pathogens and heterotrophic contaminants. This study was carried out using US municipal drinking water supplied by Cohoes Water Department in New York State. 
a)

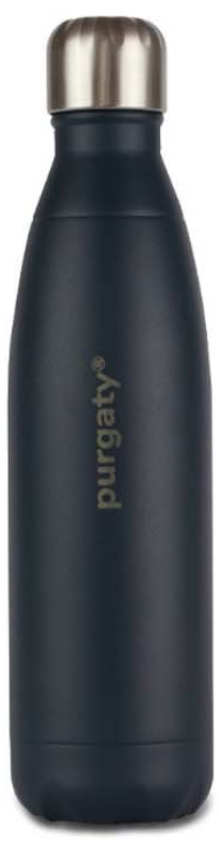

$650 \mathrm{ml}$

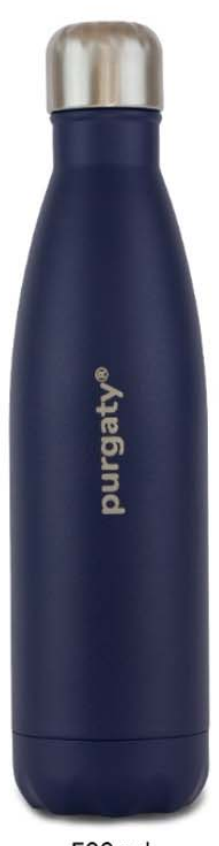

$500 \mathrm{ml}$ b)
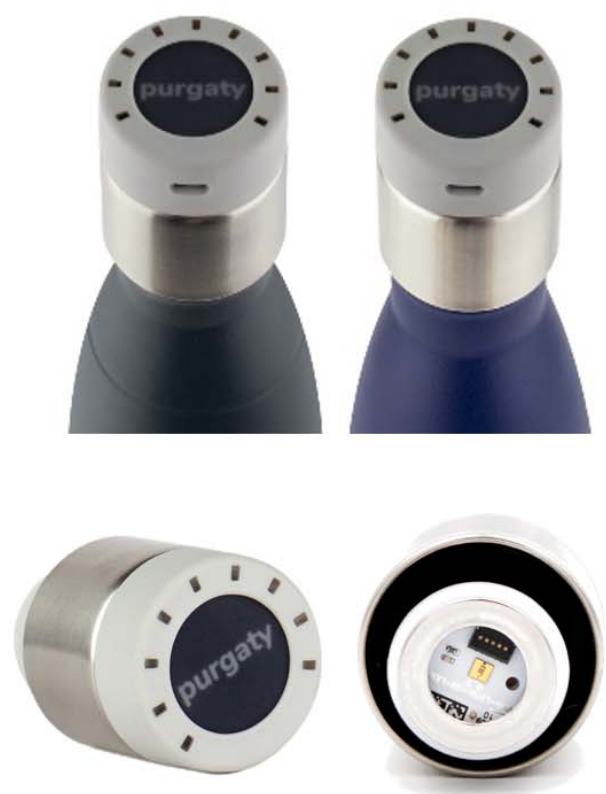

Fig.1: [a]. Test bottles whose ordinary caps can be replaced with UVC emitting purgaty ${ }^{\circledR}$ brain
Fig.1: [b]. The UVC emitting purgaty ${ }^{\circledR}$ brain threaded onto both bottles (top) and shown individually from a side view and from the bottom (bottom)

\section{Materials and Methods}

There are two bottle types of purgaty ${ }^{\circledR}$ One on the market, a $650 \mathrm{~mL}$ and a 500 $\mathrm{mL}$ version. The purgaty ${ }^{\circledR}$ brain (cap) can fit either of the bottles. The cap is rechargeable (Fig. $1[\mathrm{~b}])$.

\subsection{Disinfection Cap (purgaty ${ }^{\circledR}$ brain) Design}

The stainless-steel bottles (Fig. 1 [a]) fitted with the UVC emitting purgaty® brain (Fig. 1 [b]) offered continuous disinfection for 55 seconds. The purgaty $\AA$ brain is operated by means of a button on the top of the housing (Fig. 1 [b] and Fig. 2 [a]). Pressing the button once puts the device in standby mode, while the current charge level of the integrated battery is displayed. A second press of the button for 2 seconds activates the preset disinfection cycle for duration of 55 seconds. The unit is equipped with a safety feature, which allows the disinfection cycle to be started only after the cap has been correctly placed on the bottle (Fig. 2 [a]). A light sensor on the Printed Circuit Board (PCB) next to the UVC LED detects ambient light and interrupts the activated UVC LED in case of unthreading the cap or system damage with light entrance during a running disinfection cycle. This mechanism is designed to protect the user from contact with UVC radiation on skin or eyes. During the cycle, the LED and the sensor are periodically monitored to prevent malfunction. At the end of the 55 second cycle, the 
purgaty ${ }^{\circledR}$ brain flashes to indicate the end of the treatment process. The cap has one Klaran UVC LED (part number KL265-50U-SM-WD) that emits at $268.5 \mathrm{~nm}$ peak wavelength (Fig. 2 [b]) as confirmed using an Ocean Optics USB4000 photospectrometer.
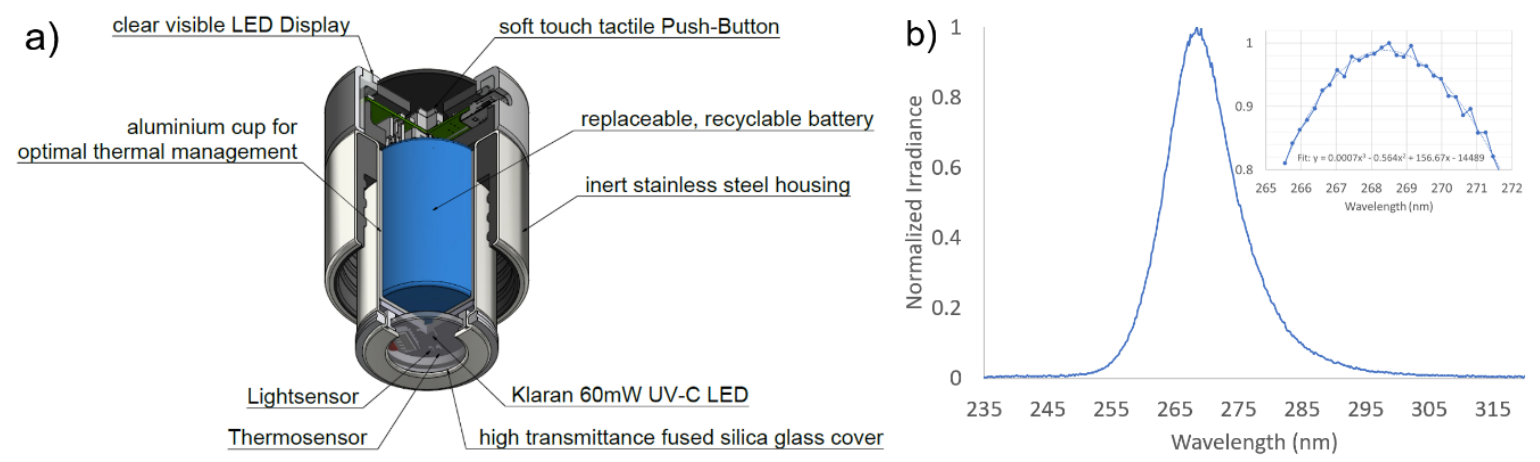

Fig. 2: [a] The purgaty® brain (cap emitting UVC) schematic [b] Measured optical spectrum of the UVC LED emission from the cap. Inset: Zoom into the peak wavelength range. A trend line has been added to the data to determine the peak wavelength value.

The thermal design is crucial for lifetime management (irreversible power degradation) as well as for ensuring the effective optical output power level (reversible thermal derating) of the UVC LED for achieving the target disinfection performance. In the purgaty $\AA$ brain, an aluminum cup is used to transfer the heat from the PCB to the outer stainless-steel shell, which releases the heat to the ambient air. This design ensures that after a continuous disinfection cycle of 55 seconds, the temperature on the aluminum PCB on which the UVC LED is mounted, does not exceed $45^{\circ} \mathrm{C}$ at an ambient temperature of $25^{\circ} \mathrm{C}$ maintaining enough optical output power levels for reliable disinfection performances. A plan-parallel $2 \mathrm{~mm}$ thick fused silica window covers the UVC LED and seals the electronics section from water and humidity. The LED package is located at $2 \mathrm{~mm}$ distance from the window.

\subsection{Bacterial cultivation and enumeration of microorganism}

Three strains of Escherichia coli ATCC 8739, Pseudomonas aeruginosa ATCC 15442, Vibrio cholerae ATCC 25872 were obtained from ATCC (Manassas, VA, USA). Stock cultures for $E$. coli and $V$. cholerae were propagated in ATCC Medium 3: Nutrient agar or nutrient broth. $P$. aeruginosa was propagated in ATCC Medium 18: Trypticase Soy Agar/Broth. All strains were plated and incubated at $37^{\circ} \mathrm{C}$ for $24 \mathrm{~h}$. One isolated colony was picked using sterile inoculation loop and used to inoculate $25 \mathrm{~mL}$ broth. Flasks with side baffles were used to enhance aeration. Cultures were incubated for $18-20 \mathrm{~h}$ at $37^{\circ} \mathrm{C}$ while shaking at $180 \mathrm{rpm}$. Culture storage was done at $-80^{\circ} \mathrm{C}(0.7 \mathrm{~mL}$ of culture with $0.7 \mathrm{~mL}$ of sterile $40 \%$ Glycerol stock). To obtain working cultures, the microorganisms were obtained from $-80^{\circ} \mathrm{C}$, streaked onto corresponding agar and incubated under same conditions. Storage of test cultures was done at $-4^{\circ} \mathrm{C}$. For UVC disinfection experimental use, each strain was harvested by centrifugation at $4000 \mathrm{rpm}$ for $10 \mathrm{~min}$. The pellets were washed using 1 X PBS three times for $10 \mathrm{~min}$. 
Between each wash, the supernatant was discarded, and the remaining pellet resuspended by vortexing. After washing thrice, the pellet was resuspended in $1 \mathrm{X}$ PBS and used to spike dechlorinated test water to achieve a final UVT value of $96 \%$ (contaminated drinking water). Dechlorination of test water was verified with a Hach DPD Free Chlorine colorimetric test. All the other test water characteristics were within the NSF/ANSI 55 standard (Tables S1-S3). The standard covers UVC disinfection systems within the range of $240 \mathrm{~nm}$ and $300 \mathrm{~nm}$ for point-of-use (POU) and point-ofentry (POE) applications [17].

\subsection{Disinfection Experiments}

The inactivation efficiency of the purgaty® One system was evaluated by inoculating the bottles with $650 \mathrm{~mL}$ or $500 \mathrm{~mL}$ of contaminated water with a UVT of $96 \%$. A single preset disinfection cycle of 55 Seconds was applied, following the manufacturer's instructions on how to use the tactile push-button of the purgaty® brain. Positive control bottles had no UVC activated as there was no use of the push-button, whereas negative control bottles contained uninoculated potable test water. The samples were thoroughly mixed after disinfection, serially diluted and processed for plating.

\subsection{Decontamination of Heterotrophic Plate Count (HPC) bacteria}

The Heterotrophic plate count (HPC) is an analytic method used to measure the variety of bacteria commonly found in water. It has no health effects as the lower the concentration of bacteria in drinking water, the better maintained the water system is. Experiments on inactivation of heterotrophic contaminants using purgaty ${ }^{\circledR}$ One system were conducted on day 0 (no water stagnation in bottles), and after 3 days of water stagnation in bottles. The standard HPC technique was used and incubation at $22^{\circ} \mathrm{C}$ and $37^{\circ} \mathrm{C}$ was applied using R2A agar [18].

\subsubsection{HPC Isolation, Identification and Phylogenetic Analyses}

Characteristic colonies (Table 2) were picked from the R2A agar plates and re-streaked for purity, incubated at $22^{\circ} \mathrm{C}$ prior to being shipped for sequencing. Submitted colony samples underwent a crude Sodium hydroxide lysis and were directly used in PCR. PCR amplification was performed according to Genewiz proprietary protocol. Following amplification, enzymatic cleanup was performed prior to primer extension sequencing (GENEWIZ, Inc., South Plainfield, NJ, USA) using the Applied Biosystems BigDye version 3.1. The reactions were then run on an Applied Biosystem's 3730xI DNA Analyzer. The primer set used in this study amplifies regions V1-V9 of the 16S gene which is roughly a 1400 base pairs amplicon. Internal sequencing primers were utilized in order to allow for the generation of a consensus sequence with the forward and reverse traces. Consensus files were quality trimmed to remove the N's. The generated $16 \mathrm{~S}$ rRNA gene sequences were then compared with those obtained from the $\mathrm{NCBI}$ database, using the program BLASTN 2.2.27 + (https://blast.ncbi.nlm.nih.gov/Blast.cgi). For phylogenetic analysis, multiple alignment of Acinetobacter 16S rRNA gene sequences using ClustalW algorithm and tree was constructed using MEGA-X [19]. The sequences from type strains used for phylogenetics were retrieved from GenBank (National Centre for Biotechnology Information; http://www.ncbi.nlm.nih.gov/), except for 
the 16S rRNA gene sequences obtained through this study. Psychrobacter cryohalolentis K5 (Accession \# NR_075055.1) was used for rooting.

\section{Results}

\subsection{Disinfection Performances Against Escherichia coli ATCC 8739, Pseudomonas aeruginosa ATCC 15442 and Vibrio cholerae ATCC 25872}

Table 1 shows the purgaty ${ }^{\circledR}$ One system effectiveness against test strains for both bottle volume types. In all cases, both test bottles obtained a LRV greater than 3 (equivalent to greater $99.9 \%$ reduction) against target microbes. Additionally, the study revealed that E. coli ATCC 29425 was more susceptible to UVC at $268.5 \mathrm{~nm}$ wavelength compared to other test strains (Table 1, Tables S1-S2). In general, the 500 $\mathrm{mL}$ bottle obtained slightly better disinfection performances compared to the $650 \mathrm{~mL}$ bottle.

Table 1: purgaty ${ }^{\circledR}$ One bottles disinfection performances against bacterial strains and environmental contaminants

\begin{tabular}{|l|l|l|}
\hline Test strain & LRV for $\mathbf{5 0 0} \mathbf{~} L$ bottle & LRV for $650 \mathbf{~} L$ bottle \\
\hline E. coli ATCC 29425 & 4.36 & 4.17 \\
\hline P. aeruginosa ATCC 15442 & 3.56 & 3.24 \\
\hline V. cholerae ATCC 25872 & 3.34 & 3.31 \\
\hline HPC day zero at $22^{\circ} \mathrm{C}$ & 4.44 & 4.40 \\
\hline HPC day zero at $37^{\circ} \mathrm{C}$ & 3.96 & 3.36 \\
\hline HPC after 3 days stagnation at $22^{\circ} \mathrm{C}$ & 3.95 & 3.53 \\
\hline HPC after 3 days stagnation at $37^{\circ} \mathrm{C}$ & 3.62 & 3.11 \\
\hline
\end{tabular}

\subsection{Disinfection Performance Against HPC Bacteria}

HPC bacteria were present in all untreated water samples with concentrations ranging from $5.0 \times 10^{5}$ to $5.67 \times 10^{5} \mathrm{CFU} / \mathrm{mL}$ (Table S3). Disinfection using the purgaty ${ }^{\circledR}$ One system reduced the microbial load of heterotrophic bacteria by $>$ LRV3 $(99.9 \%$ 
reduction) (Table 1, Table S3). Additionally, there was HPC bacterial selection by UVC exposure. The selection of UVC resistant bacteria is not new, as some strains obtained in this study such as Methylobacterium have been isolated previously [20] .

\subsubsection{Identification and Phylogenetic Analysis of HPC Bacteria}

Eleven bacterial monocultures with distinct characteristics isolated from UVC on condition were selected for molecular identification. They were identified as:

Methylorubrum populi, Sphingomonas ursincola, Brevundimonas nasdae, Bradyrhizobium yuanmingense, Brevibacillus choshinensis, Brevibacillus nitrificans, Roseomonas mucosa, Methylorubrum rhodesianum, Cupriavidus lacunae and Caulobacter segnis (Table 2). Two most abundant isolates were however obtained under non-UVC treated conditions (UVC not applied)). These were identified as Acinetobacter johnsonii and Methylibium petroleiphilum. These two strains were UVC sensitive, thus accounting for the high HPC bacteria decontamination (Table 1, Table S3). All Isolates belonged to either Phylum Proteobacteria or Firmicutes (Table 2). 
Table 2: Identification of the HPC bacterial isolated from this study using 16S rRNA gene

\begin{tabular}{|l|l|l|l|l|l|l|}
\hline $\begin{array}{l}\text { Strain } \\
\text { name }\end{array}$ & $\begin{array}{l}\text { Colony } \\
\text { Characteristics }\end{array}$ & Accession & Organism & Closet relative & $\begin{array}{l}\% \\
\text { similarity }\end{array}$ & Phylum \\
\hline Poff1 & White & MW167646 & Acinetobacter johnsonii & $\begin{array}{l}\text { A. johnsonii ATCC } \\
17909\end{array}$ & 99.18 & Proteobacteria \\
\hline Poff2 & Yellowish & MW167647 & $\begin{array}{l}\text { Methylibium } \\
\text { petroleiphilum }\end{array}$ & petroleiphilum PM1 & 99.86 & Proteobacteria \\
\hline Poff3 & White & MW167648 & Acinetobacter johnsonii & $\begin{array}{l}\text { A. johnsonii ATCC } \\
17909\end{array}$ & 99.39 & Proteobacteria \\
\hline Pon1 & Pink & MW167649 & Methylorubrum populi & M. populi BJ001 & 99.65 & Proteobacteria \\
\hline Pon2 & Yellowish & MW167650 & $\begin{array}{l}\text { Sphingomonas } \\
\text { ursincola }\end{array}$ & S. ursincola DSM 9006 & 99.72 & Proteobacteria \\
\hline Pon3 & White & MW167651 & Brevundimonas nasdae & B. nasdae W1-2B & 99.28 & Proteobacteria \\
\hline Pon4 & White & MW167652 & $\begin{array}{l}\text { Bradyrhizobium } \\
\text { yuanmingense }\end{array}$ & $\begin{array}{l}\text { B. yuanmingense } \\
\text { NBRC 100594 }\end{array}$ & 99.86 & Proteobacteria \\
\hline Pon5 & Pink & MW167653 & $\begin{array}{l}\text { Brevibacillus } \\
\text { choshinensis }\end{array}$ & $\begin{array}{l}\text { B. choshinensis NBRC } \\
15518\end{array}$ & 99.45 & Firmicutes \\
\hline Pon6 & White & MW167654 & $\begin{array}{l}\text { Brevibacillus nitrificans } \\
\text { B. nitrificans DA2 }\end{array}$ & 99.39 & Firmicutes \\
\hline Pon7 & Pink & MW167655 & Roseomonas mucosa & R. mucosa MDA5527 & 99.72 & Proteobacteria \\
\hline Pon8 & White & MW167656 & $\begin{array}{l}\text { Brevibacillus nitrificans } \\
\text { B. nitrificans DA2 }\end{array}$ & 99.25 & Firmicutes \\
\hline Pon9 & Pink & MW167657 & $\begin{array}{l}\text { Methylorubrum } \\
\text { rhodesianum }\end{array}$ & $\begin{array}{l}\text { M. rhodesianum } \\
\text { NCIMB 13779 }\end{array}$ & 99.23 & Proteobacteria \\
\hline Pon10 & White & MW167658 & Cupriavidus lacunae & C. lacunae S23 & 98.84 & Proteobacteria \\
\hline Pon11 & White & MW167659 & Caulobacter segnis & C. segnis ATCC 21756 & 99.43 & Proteobacteria \\
\hline
\end{tabular}

Note: Poff: purgaty study isolates obtained from UVC off conditions (No UVC applied). These were the most abundant.

Pon: purgaty isolates obtained from UVC on conditions (UVC applied) 
Taxonomic classification of HPC isolates using 16S rRNA gene identified Acinetobacter johnsonii and Methylibium petroleiphilum to be most dominant in untreated water. These two representatives of Phylum Proteobacteria were sensitive to UVC irradiation and thus not selected by UVC (+UVC condition). Strain Poff1, identified as Acinetobacter johnsonii which was isolated under UVC off condition (-UVC) belongs to the same Genus as Acinetobacter baumannii, a multidrug resistant nosocomial pathogen of global concern [21]. The study sought to confirm if the two species did not cluster together to rule out any concerns regarding the presence of Acinetobacter johnsonii in drinking water. Phylogenetic analysis revealed that they do not cluster together (Fig. S1). Further, based on literature from previous studies, $A$. johnsonii has been confirmed to rarely causes human infections and has been found to be sensitive to virtually all antibiotics [22].

\section{Discussion}

Data from this study revealed $>$ LRV3 in test bacteria, further supporting accumulating evidence for high disinfection activities of portable UVC devices [14]. The study demonstrated high disinfection performance against E. coli ATCC 29425 (99.99\% reduction). This can be attributed to relatively low \%GC content of E. coli (50.68\%) [23] and its peak UVC sensitivity [24]. Although the Vibrio Genus has low \%GC content ( 47\%), the presence of more elaborate DNA repair/protection processes make them less susceptible against UVC irradiation [25], thus obtaining $99.9 \%$ disinfection under similar test conditions (Table 1). This is in comparison with $P$. aeruginosa ATCC 15442 which has higher $\%$ GC content $66.17 \%$ (https://genomes.atcc.org/genomes/371a35eda24d4ddd).

Even after 3 days of water stagnation, the use of purgaty $\AA$ one system effectively decontaminated that HPC bacteria, obtaining $<500 \mathrm{CFU} / \mathrm{mL}$, as recommended [26]. All the UVC selected bacteria are of rare to no public health concern. For instance, Brevibacillus nitrificans is a heterotrophic nitrifying bacterium [27] whose genera, Brevibacillus is one of the most widespread and is found in diverse environmental habitats, including drinking water [28]. The study revealed that phylum proteobacteria as most frequent of the identified isolates (Table 1). Although drinking water has complex microbiota, previous characterization studies have confirmed that phylum Proteobacteria is the most frequent in drinking water [29].

Results from this study indicate that UVC exposure of static water in devices such as the purgaty ${ }^{\circledR}$ One systems (cap+bottle) can reduce elevated initial bacterial loads. These devices could be useful in environments where people are vulnerable to pathogens. Applications include but are not limited to those related to travel medicine, healthcare facilities where patients are vulnerable to opportunistic pathogens, hiking, remote military installations and regions having water potability challenges. 


\section{Conclusion}

This study investigated the efficacy of the purgaty ${ }^{\circledR}$ One system (bottle + cap) on bacterial inactivation in a stagnant water disinfection setup. The two types of stainlesssteel water bottles $(650 \mathrm{~mL}$ and $500 \mathrm{~mL}$ ) achieved more than $99.99 \%$ inactivation efficacy against $E$. coli ATCC 29425 after a single treatment cycle of 55 seconds preset by the purgaty ${ }^{\circledR}$ brain (cap), including a Klaran UVC LED with peak wavelength of 268.5nm. For $P$. aeruginosa ATCC 15442 and Vibrio cholerae ATCC 25872, an inactivation efficacy of more than $99.9 \%$ was achieved. The bottles were also able to inactivate heterotrophic contaminants with more than $99.9 \%$ reduction, even after 3 days of water stagnation in the bottles. These results demonstrate the ability of consistent disinfection performances of a mobile, simple-to-use and safe consumer water bottle appliance with a UVC disinfection feature including a single UVC LED only, which has extended application potential during emergency preparedness such as for flooding situations, outdoor activities like mountain climbing, military use especially during operations in remote areas as well as consumer home use when in doubt of water potability. Lastly, these results offer fundamental evidence on how travel medicine can benefit from the use of personal UVC devices to ensure eradication of enteric pathogens.

\section{Data availability}

The 16S rRNA gene sequences obtained from this study are available through GenBank (https://www.ncbi.nlm.nih.gov/genbank/) under the accession numbers MW167646-MW167659. The Spectral data is available via https://doi.org/10.6084/m9.figshare.13144538.v1.

\section{Conflict of interests}

Richard M. Mariita, Sébastien A. Blumenstein and Rajul V. Randive work for Crystal IS Inc., an Asahi Kasei Company that manufactures UVC-LEDs. Christian M. Beckert and Thomas Gombas work for purgaty, the innovators of stainless-steel drinking water bottle with cap which inactivates microorganisms. Purgaty employees did not have any role in the microbial disinfection study design, data collection and analysis and writing of manuscript, but had major contribution in the understanding of purgaty ${ }^{\circledR}$ one system, read and approved final manuscript.

\section{Funding}

This research did not receive any specific grant from funding agencies in the public or commercial, or not-for-profit sectors. 
bioRxiv preprint doi: https://doi.org/10.1101/2021.06.02.446792; this version posted June 3, 2021. The copyright holder for this preprint (which was not certified by peer review) is the author/funder, who has granted bioRxiv a license to display the preprint in perpetuity. It is made available under aCC-BY-ND 4.0 International license.

\section{Acknowledgements}

Authors wish to thank Michelle Lottridge, Chris Scully, Amy Miller, Jeremy Abel, Stephan Gadhof, Paul Bilton, Dr. Kevin Kahn and James Peterson for providing help during research and proofreading the manuscript. 


\section{References}

[1] Ericsson CD, Steffen R, Backer H. Water Disinfection for International and Wilderness Travelers. Clinical Infectious Diseases 2002;34:355-64. https://doi.org/10.1086/324747.

[2] Ashbolt NJ. Microbial contamination of drinking water and disease outcomes in developing regions. Toxicology 2004;198:229-38. https://doi.org/10.1016/j.tox.2004.01.030.

[3] Medema, GJ, Payment P, Dufour A, Robertson W, Waite M, Hunter P, Kirby R, Anderson $Y$ Cabral. Safe drinking water: an ongoing challenge. In: Assessing microbial safety of drinking water. Improving approaches and method. London: WHO \& OECD, IWA Publishing; 2003.

[4] Schlosser O, Robert C, Bourderioux C, Rey M, de Roubin MR. Bacterial Removal from Inexpensive Portable Water Treatment Systems for Travelers. Journal of Travel Medicine 2001;8:12-8. https://doi.org/10.2310/7060.2001.5143.

[5] Umar M, Roddick F, Fan L. Moving from the traditional paradigm of pathogen inactivation to controlling antibiotic resistance in water - Role of ultraviolet irradiation. Science of The Total Environment 2019;662:923-39. https://doi.org/10.1016/j.scitotenv.2019.01.289.

[6] Fagunwa OE, Olanbiwoninu AA. Accelerating the sustainable development goals through microbiology: some efforts and opportunities. Access Microbiology 2020:acmi000112.

[7] Cabral JP. Water microbiology. Bacterial pathogens and water. International Journal of Environmental Research and Public Health 2010;7:3657-703.

[8] Heidelberg JF, Eisen JA, Nelson WC, Clayton RA, Gwinn ML, Dodson RJ, et al. DNA sequence of both chromosomes of the cholera pathogen Vibrio cholerae. Nature 2000;406:477-83. https://doi.org/10.1038/35020000.

[9] Vezzulli L, Grande C, Reid PC, Hélaouët P, Edwards M, Höfle MG, et al. Climate influence on Vibrio and associated human diseases during the past half-century in the coastal North Atlantic. Proc Natl Acad Sci U S A 2016;113:E5062-71. https://doi.org/10.1073/pnas.1609157113.

[10] Kanamori H, Weber DJ, Rutala WA. Healthcare Outbreaks Associated With a Water Reservoir and Infection Prevention Strategies. Clinical Infectious Diseases 2016;62:1423-35. https://doi.org/10.1093/cid/ciw122.

[11] Lizzadro J, Mazzotta M, Girolamini L, Dormi A, Pellati T, Cristino S. Comparison between Two Types of Dental Unit Waterlines: How Evaluation of Microbiological Contamination Can Support Risk Containment. International Journal of Environmental Research and Public Health 2019;16:328.

[12] World Health Organization. Global water supply and sanitation assessment 2000 report. World Health Organization; 2000.

[13] World Health Organization. Ultraviolet Radiation and Health. https://www.who.int/uv/uv_and_health/en/; 2014.

[14] Timmermann LF, Ritter K, Hillebrandt D, Küpper T. Drinking water treatment with ultraviolet light for travelers - Evaluation of a mobile lightweight system. Travel Medicine and Infectious Disease 2015;13:466-74. https://doi.org/10.1016/j.tmaid.2015.10.005. 
[15] Dai T, Vrahas MS, Murray CK, Hamblin MR. Ultraviolet C irradiation: an alternative antimicrobial approach to localized infections? Expert Rev Anti Infect Ther 2012;10:185-95. https://doi.org/10.1586/eri.11.166.

[16] Gora SL, Rauch KD, Ontiveros CC, Stoddart AK, Gagnon GA. Inactivation of biofilm-bound Pseudomonas aeruginosa bacteria using UVC light emitting diodes (UVC LEDs). Water Research 2019;151:193-202. https://doi.org/10.1016/j.watres.2018.12.021.

[17] NSF International Standard. NSF/ANSI 55: Ultraviolet Microbiological Water Treatment Systems 2019.

[18] Gensberger ET, Gössl E-M, Antonielli L, Sessitsch A, Kostić T. Effect of different heterotrophic plate count methods on the estimation of the composition of the culturable microbial community. PeerJ 2015;3:e862-e862. https://doi.org/10.7717/peerj.862.

[19] Kumar S, Stecher G, Li M, Knyaz C, Tamura K. MEGA X: molecular evolutionary genetics analysis across computing platforms. Molecular Biology and Evolution 2018;35:1547-9.

[20] Oguma K, Kanazawa K, Kasuga I, Takizawa S. Effects of UV Irradiation by Light Emitting Diodes on Heterotrophic Bacteria in Tap Water. Photochemistry and Photobiology 2018;94:570-6. https://doi.org/10.1111/php.12891.

[21] Antunes L, Visca P, Towner KJ. Acinetobacter baumannii: evolution of a global pathogen. Pathogens and Disease 2014;71:292-301.

[22] Montaña S, Schramm ST, Traglia GM, Chiem K, Parmeciano Di Noto G, Almuzara $\mathrm{M}$, et al. The genetic analysis of an Acinetobacter johnsonii clinical strain evidenced the presence of horizontal genetic transfer. PLoS One 2016;11:e0161528.

[23] Engelbrecht KC, Putonti C, Koenig DW, Wolfe AJ. Draft Genome Sequence of Escherichia coli K-12 (ATCC 29425). Genome Announcements 2017;5.

[24] Green A, Popović V, Pierscianowski J, Biancaniello M, Warriner K, Koutchma T. Inactivation of Escherichia coli, Listeria and Salmonella by single and multiple wavelength ultraviolet-light emitting diodes. Innovative Food Science \& Emerging Technologies 2018;47:353-61. https://doi.org/10.1016/j.ifset.2018.03.019.

[25] Krin E, Pierlé SA, Sismeiro O, Jagla B, Dillies M-A, Varet H, et al. Expansion of the SOS regulon of Vibrio cholerae through extensive transcriptome analysis and experimental validation. BMC Genomics 2018;19:373.

[26] Kohn WG, Collins AS, Cleveland JL, Harte JA, Eklund KJ, Malvitz DM. Guidelines for infection control in dental health-care settings-2003 2003.

[27] Takebe F, Hirota K, Nodasaka Y, Yumoto I. Brevibacillus nitrificans sp. nov., a nitrifying bacterium isolated from a microbiological agent for enhancing microbial digestion in sewage treatment tanks. International Journal of Systematic and Evolutionary Microbiology 2012;62:2121-6.

[28] Panda AK, Bisht SS, DeMondal S, Kumar NS, Gurusubramanian G, Panigrahi AK. Brevibacillus as a biological tool: a short review. Antonie Van Leeuwenhoek 2014;105:623-39.

[29] Vaz-Moreira I, Nunes OC, Manaia CM. Ubiquitous and persistent Proteobacteria and other Gram-negative bacteria in drinking water. Science of the Total Environment 2017;586:1141-9. 